\title{
New technique for construction of tissue heart valves
}

\author{
CHANYA MANOTHAYA, SOMSAK VATTANAPAT, AND CHALARD SOMABUTR \\ From the Departments of Surgery and Medicine, Faculty of Medicine, Chulalongkorn Hospital, Chulalo:tgkorn \\ University, Bangkok, Thailand
}

ABSTRACT A new technique for the construction of frame-supported tissue heart valves made of dura mater is presented. Three symmetrical pieces of pentagon-shaped tissue are used instead of the conventional quadrangular shape. A symmetrical trileaflet valve with adequate coaptation and less spherical formation of the cusps is obtained. The design characteristics suggest that regurgitation through the valve will be prevented, there will be less resistance to flow, and less strain on the leaflets during closure. This technique has been applied clinically in 37 patients with very satisfactory early results. A longer follow-up of the patients is necessary for comparison of the results with other techniques of construction.

The improved results of heart valve replacement depend on many factors. These include improvement in materials and designs of prosthetic devices, and the methods of preservation and techniques of construction of bioprostheses, as well as advances in surgical technique.

Bioprostheses have gained popularity in recent years, because of their superior haemodynamic properties and freedom from thromboembolism. Improved methods of preservation and techniques of construction seemed to increase durability. Long-term results have been reported for various types of tissue valve-for example, porcine valves, calf pericardium, and homologous dura mater valves. ${ }^{1-4}$

The object of this paper is to present a new technique of construction of frame-supported tissue valves.

\section{Technique}

A moulding die of symmetrical trileaflet core is prepared (fig 1). The angle between the cusp and the baseline is greater than $45^{\circ}$. A piece of tissue is imprinted in one of these cusps and cut out along the margin of the cusp of the moulding die (fig 2). This piece of tissue is then spread out and outlined as shown (fig 3).

In this way, three symmetrical pentagonshaped pieces of tissue are obtained by using a steel template. The width and length vary according to the size of the frame. (Fascia lata

Address for reprint requests: Chanya Manothaya, Department of Surgery, Chulalongkorn Hospital, Bangkok 5, Thailand. heart valve graft support. Manufactured by BIOMED Engineering Ltd, Yorkshire, England.)

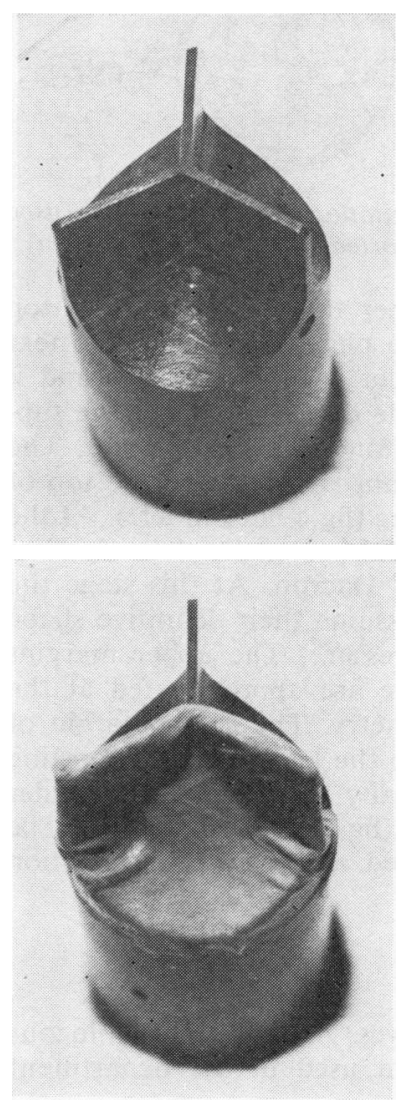

Fig 1 A moulding die of trileaflet core.

Fig 2 A piece of tissue is imprinted and cut out along the margin of the cusp. 


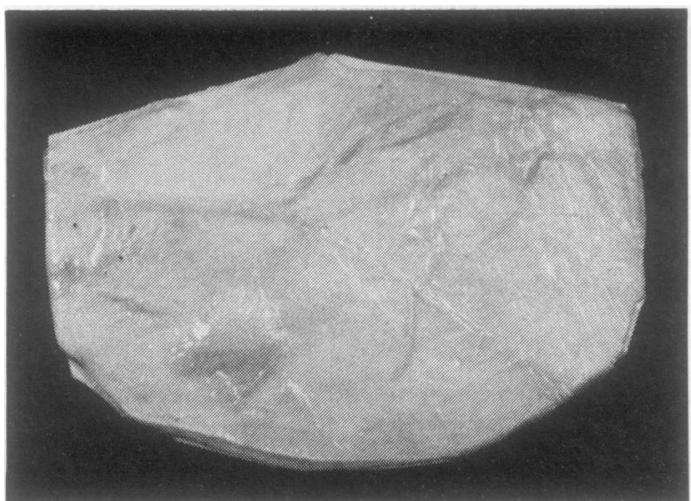

Fig 3 Tissue obtained from the moulaing die.

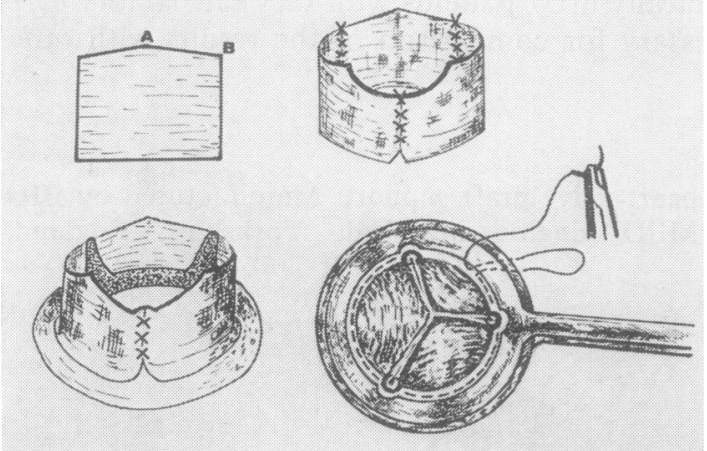

Fig 4 Schematic presentation of the technique used to construct frame-supported tissue valves (see text).

Point $A$ is $3 \mathrm{~mm}$ higher than point $B$ (fig 4 top left). Each side of one piece is sewn to the next piece to form a cylinder (fig 4 top right), and is placed on the outer side of the prongs of the supporting frame representing the commissures. The upper edge of each seam is sutured to the top of each commissural prong (fig 4 bottom left). At the top of each commissural prong the tissue is reinforced with a piece of Dacron. At this stage the cusps are allowed to assume their definitive shape without any digital pressure. The upper margins of each piece of tissue are approximated at the centre to ensure symmetry. The lower margin of the tissue is stitched to the base of the supporting frame while the specially designed frame holder holds them together (fig 4 bottom right). The valve is then completed and ready for insertion (figs 5 and 6)

\section{Clinical experience}

Biological tissue valves made of homologous dura mater have been used in the department

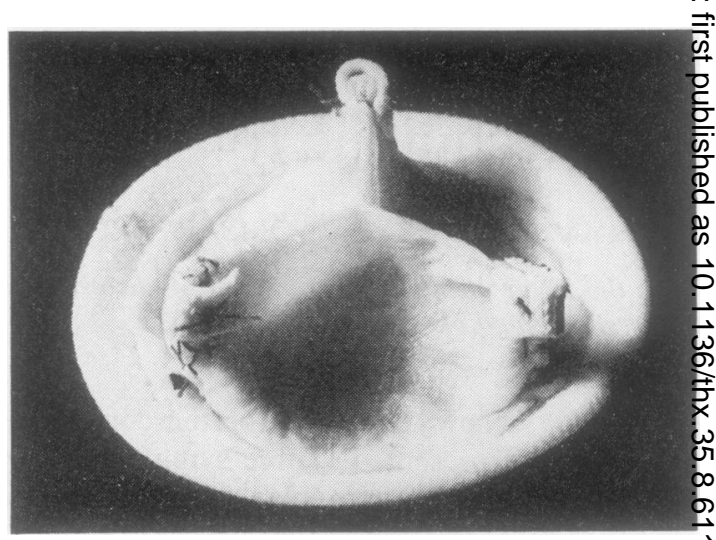

Fig 5 Outflow aspect of dura mater valve.

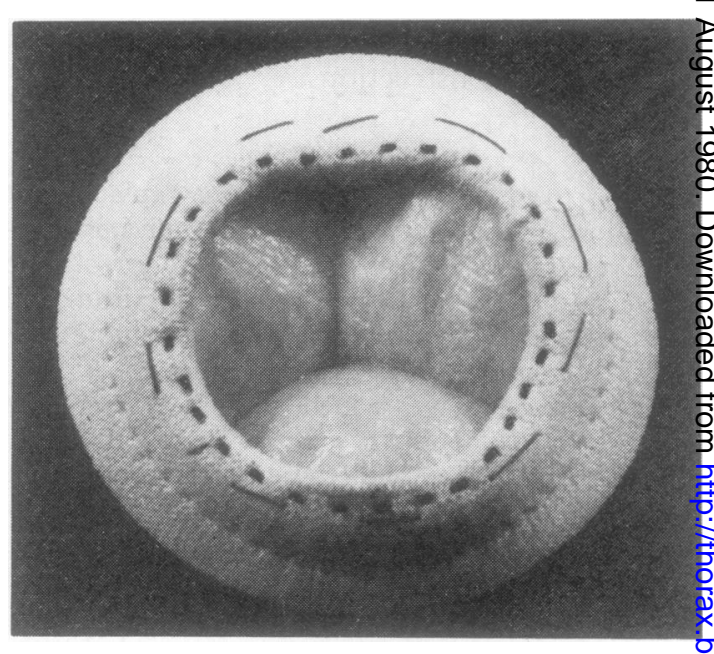

Fig 6 Inflow aspect of dura mater valve.

of surgery, Chulalongkorn Hospital Medica School since January 1976. The dura mater was preserved and sterilised in $98 \%$ glycerol at room temperature. ${ }^{5}$ Up to December 1978 , a total of 41 dura mater valves obtained by the new tech nique of construction have been inserted in $3 \phi$ patients by one of us (CM). The types of operaAs tion and sizes of the supporting frame are shown in table 1. One patient had a mitral valvoo plasty, three had a tricuspid annuloplasty, and three had an aortic commissurotomy.

\section{Results}

In this group of patients, two early death\$ $(5.4 \%)$ and two late deaths $(5.4 \%)$ occurred, aro overall mortality of $10 \cdot 8 \%$. The causes of death are listed in table 2. 
Table 1 Types of operation and frame sizes

\begin{tabular}{lccccc}
\hline Types of operation & Number of patients & \multicolumn{3}{c}{ Frame size (ID) } \\
& & $20 \mathrm{~mm}$ & 22 $\mathrm{mm}$ & $24 \mathrm{~mm}$ \\
\hline AVR & 7 & 7 & - & - \\
MVR & 25 & 2 & 17 & 6 \\
TVR & 1 & - & - & 1 \\
AVR and MVR & 3 & 3 & - & 3 \\
MVR and TVR & 1 & - & - & 2 \\
Total & 37 & 12 & 17 & 12 \\
\hline
\end{tabular}

AVR = aortic valve replacement.

MVR = mitral valve replacement.

$T V R=$ tricuspid valve replacement.

Table 2 Causes of death in four patients

\begin{tabular}{ll}
\hline Causes of death & Operations \\
\hline Early (within one month) & \\
Myocardial infarction (1) & TVR \\
Pulmonary embolism (1) & MVR \\
Late (after one month) & Generalised sepsis (1) \\
Fire accident (1) & MVR and MVR \\
\hline
\end{tabular}

Abbreviations as in Table 1

Thirty-three patients who survived operation have been followed up. Two patients were lost to follow-up six and 10 months after mitral valve replacement. The overall results are listed in table 3. All patients have shown clinical improvement according to the criteria of the New York Heart Association. Many of them have shown radiological improvement.

Table 3 Overall results in 37 patients

\begin{tabular}{lcccr}
\hline Years & 1976 & 1977 & 1978 & Total (\%) \\
\hline $\begin{array}{l}\text { Number of patients } \\
\text { Early deaths }\end{array}$ & 14 & 7 & 16 & $37(100 \%)$ \\
Late deaths & 1 & - & - & $2(5.4 \%)$ \\
$\begin{array}{l}\text { Lost to follow-up } \\
\text { Survivors at the end } \\
\text { of } 1978\end{array}$ & 2 & - & 1 & $2(5.4 \%)$ \\
\hline
\end{tabular}

A regurgitant murmur was heard in only one patient, who had had a mitral valve replace. ment. The murmur developed immediately after operation, but the patient's condition and radiographic findings continue to improve.

Only seven patients who survived more than one year after the operation agreed to recatheterisation, four patients after aortic valve replacement, and three patients after mitral valve replacement. In two cases the aortic valve could not be traversed. There was no significant pressure gradient across the valves and no evidence of regurgitation (table 4).
Table 4 Haemodynamic study one year after valve replacement

\begin{tabular}{llll}
\hline Case & Valve & Sizes (mm ID) & $\begin{array}{l}\text { Pressure gradient } \\
\mathrm{mm} \mathrm{Hg}\end{array}$ \\
\hline 1 & AVR & 20 & $0^{*}$ \\
2 & AVR & 20 & $14^{*}$ \\
3 & MVR & 24 & 0 \\
4 & MVR & 22 & 2 \\
5 & MVR & 22 & 3 \\
\hline Abbreviations as in Table 1 & & \\
*Peak systolic gradient & &
\end{tabular}

\section{Discussion}

Since the first frame-mounted fascia lata valve was introduced in $1969,{ }^{6}$ several modifications have been made to improve the haemodynamic function and durability of the valves. ${ }^{7-10}$

To compare the characteristics of this valve with valves prepared using the conventional quadrangular shape of tissue, three similar pieces of pentagon-shaped tissue were obtained by using a steel template (fig 7). The area above

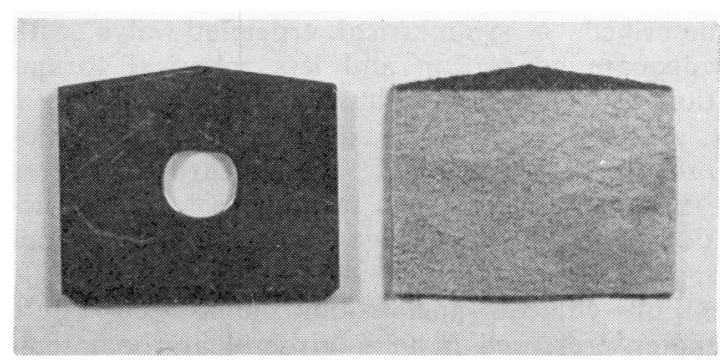

Fig 7 Tissue (right) which is cut by using a pentagon-shaped steel template (left). Area above the conventional quadrangular shape is painted $a$ dark colour.

the conventional quadrangular shape was painted with a dark colour. When the trileaflet valve was completed, one leaflet was removed to demonstrate the area of coaptation and the angle between the cusps and base of the supporting frame (fig 8). It was clearly demonstrated that if conventional quadrangular pieces of tissue were used, a small area of coaptation only was formed compared with at least $3 \mathrm{~mm}$ of coaptation when pentagon-shaped pieces of tissue were used.

The same degree of coaptation could be obtained using conventional quadrangular pieces of tissue by pulling up the free end of each piece of tissue. The angle between each cusp and the base of the supporting frame would be smaller, which would result in a more spherical 


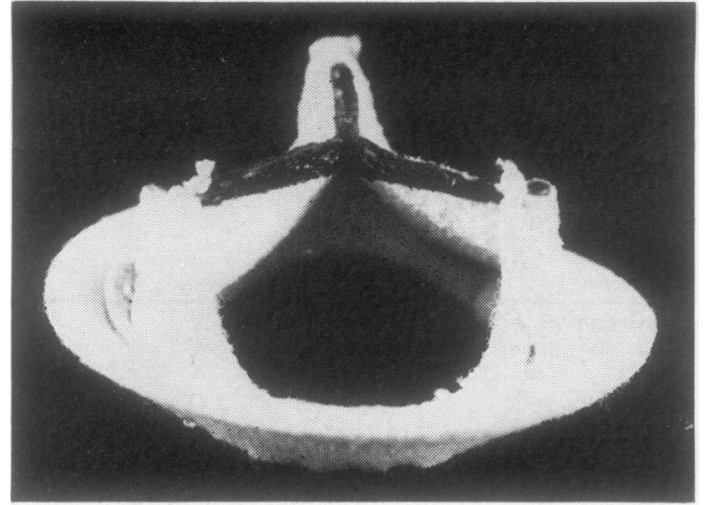

Fig 8 To demonstrate area of coaptation and angle between the cusps and base line.

formation of the cusps. From the basic principles of force, we know that the more spherical formation of the cusp, the more resistance of the valve to opening and the more strain on the cusps during closure.

Using the new technique of construction as described, a symmetrical trileaflet valve with adequate coaptation and less spherical formation of the cusps is obtained.

At present, several commercially made bioprostheses are available. Many cardiac centres still establish their own techniques for construction of tissue heart valves, especially in developing countries.

For clinical application, homologous dura mater preserved in $98 \%$ glycerol at room temperature has been used to construct the valve because of its excellent properties as a valve substitute. ${ }^{2}{ }^{3} \mathrm{~A}$ longer follow-up and more cases for haemodynamic evaluation of this technique are needed to clarify the results.

\section{References}

1 Ionescu MI, Pakrashi BC, Mary DAS, Bartek IT Wooler GH. Long-term evaluation of tissue valves. J Thorac Cardiovasc Surg 1974; 68 @़ 361-79.

2 Nuno-Conceicão A, Puig LB, Verginelli G, IryiàK, Bittencourt D, Zerbini EJ. Homologous dura mater cardiac valves: structural aspects of eigh? implanted valves. J Thorac Cardiovasc Surz 1975; 70:499-508.

3 Puig LB, Verginelli G, Iryia K et al. Homologous ్ dura mater cardiac valves: study of 533 surgicaj cases. J Thorac Cardiovasc Surg 1975; 69:722-8.

4 Carpentier A. Discussion on long-term follow-up after isolated aortic valve replacement. $J$ Thorac Cardiovasc Surg 1977; 74:887-8.

5 Pigossi N, Raia A, Lex A et al. Estudo experic mental e clínico sôbre o emprêgo, como implantec da dura máter homógena conservada em glicerina ${ }^{+}$ á temperatura ambiente $A M B 1971 ; 17: 263-78$. $\overrightarrow{0}$

6 Ionescu MI, Ross DN. Heart valve replacemeng with autologous fascia lata. Lancet $1969 ; 2: 335-8$

7 Ionescu MI, Pakrashi BC, Holden MP, MarQ DA, Wooler GH. Results of aortic valve replaces ment with frame-supported fascia lata and peri cardial grafts. J Thorac Cardiovasc Surg 1972\%
64:340-53.

8 Dubiel WT, Hallen A, Johansson L. Aortic valve replacement with frame-supported autologous fascia grafts. Scand J Thorac Cardiovasc Surg 1975; 9:94-107.

9 Edwards WS, Karp RB, Robillard D, Kerr AR Mitral and aortic valve replacement with fasci lata on a frame. J Thorac Cardiovasc Surg 1969 58:854-8.

10 Bartek IT, Holden MP, Ionescu MI. Framemounted tissue heart valves: technique of con struction. Thorax 1974; 29:51-5. 